\title{
Community Development as a CSR Strategy for Sri Lanka
}

\author{
Kumudini Heenetigala \\ Victoria University, Australia
}

\begin{abstract}
The purpose of this paper was to investigate the corporate social responsibility (CSR) practices related to community development (CD) by Sri Lankan companies. This article investigated CSR practices related to community development in Sri Lanka from secondary data in websites, integrated reports and sustainability reports from a sample of 30 companies in the top 50 Companies in the Sri Lanka's LMD 100 for the year 2013. Descriptive statistics were employed to investigate the reporting practices. Community development practices of the top 10 companies were investigated in-depth using content analysis. Results showed that $90 \%$ of the companies reported their CSR activities, and were moving towards integrated reporting. The majority of the CSR related CD practices were conducted to improve the quality of lives of people living in rural areas and they were mainly to provide better education, health facilities and livelihood development. However, education was the top most priority by the companies. In-depth analysis of this study is limited to the top 10 companies in the LMD 100 which are ranked among the most respected companies. This study implies that education is a top most priority among CSR practices in Sri Lanka because it improves the living standards and also contribute to economic development. This paper contributes to understanding the community development practices in developing countries in which a corporate sector should engage as their CSR if they are to have a strong impact on economic development.
\end{abstract}

\section{Keywords}

Corporate Social Responsibility, Community Development, Stakeholder Theory, Sri Lanka

\section{Introduction}

Community Development (CD) is an important aspect of corporate social responsibility (CSR) in developing countries. It can have a strong impact on economic development and enable social change through economic empowerment, reduced inequality and improvement in the health and welfare of the those socially excluded in the population (Werner, 2009). Rural communities form a large part of societies in developing countries and are considered poor (Heenetigala, 2011). Much economic development in rural communities, in both emerging market countries and developing countries, is hampered as a result of internal conflict, ethnic wars and floods. As a result, communities in rural areas are unable to reach a higher quality of life as well as lower access to education, medical and social assistance and under-developed infrastructure (Akresh, Lucchetti, \& Thirumurthy, 2012; Dupas \& Robinson, 2012; Van Niekerk, 2012).

Even though this is the responsibility of the governments of the countries, lack of resources has left this gap to be covered by the private sector organisations (Kolk \& Lenfant, 2010; Valente \& Crane, 2010). Furthermore, profits from businesses do not go to the poor directly from taxes as government

Copyright (C) 2016 Victoria. This document has been published as part of the Journal of Law and Governance in both online and print formats. Educational and non-profit institutions are granted a non-exclusive licence to utilise this document in whole or in part for personal or classroom use without fee, provided that correct attribution and citation are made and this copyright statement is reproduced. Any other usage is prohibited without the express permission of the publisher. revenue for the development of public services and infrastructure (Werner, 2009). Werner concluded that, leaving the development of communities to NGO's or other development agencies has little impact on the development. Attention of private sector companies to their CSR strategies has had an impact on the social status of socially excluded populations (Muthuri, Moon, \& Idemudia, 2012; 
Werner, 2009). It creates more jobs, better educated and healthy rural population who previously did not have access to health, education and training facilities. Muthuri et al. (2012) refers to work of Hamann, Woolman., and Sprague (2008) and Idemudia (2007) which states that companies in developing countries provide a range of social initiatives for the local communities such as health care, education, economic welfare, infrastructure development, communication and environmental protection. Hence, a community is an important stakeholder of a company operating in a developing country. The aim of this study was to investigate CSR related community development practices conducted by the corporate sector in Sri Lanka. .

\section{CSR and Community Development}

CSR has been referred to as "how companies mitigate any negative impacts, while at the same time maximizing the positive influences that their businesses have on society, the environment and the financial well-being within their communities of influence" (Fisher, Greenen, Jurcevic, McClintock, \& Davis, 2009).

The World Business Council for Sustainable development (WBCSD) developed their definition for CSR based on the CSR dialogue with eight countries from developed and developing countries. Developed countries base their definition on corporate strategy and future generation, whereas developing countries emphasize CSR is related to community which has an impact on the economic development. As a result the following definition was developed at the CSR dialogue in the Netherlands in 1998:

'Corporate social responsibility is the continuing commitment by business to behave ethically and contribute to economic development while improving the quality of life of the workforce and their families as well as of the local community and society at large'. (WBCSD, 1998).

In order to understand the role CSR plays in community development, it is important to define community. According to Ismail (2009 p 203) a community is "a group of people sharing a common purpose, who are interdependent for the fulfillment of certain needs, who live in close proximity and interact on a regular basis". However, in the current society, identifying a community is a complex and contested task, due to the shared traits such as geographical territory, religion, culture, history, kinship etc. As well, people may have multiple and overlapping identities which can change overtime. As a result, definition of a community is a construct (Kapelus, 2002).

Ajayi (1995) considers community development is a process by which human beings can become more competent to live with and gain some control over local conditions and the changing world. Therefore, community development is a process by which the efforts of the people themselves are linked with those of the government to improve the socio-economic and cultural conditions of the community, thus enabling them to contribute more fully to national progress (Obibuaku, 1983). Accordingly, Ismail (2009 p 203) refers to Community development as the "initiatives undertaken by a community with partnership with external organisations or corporations to empower individuals and groups of people by providing these groups with the skills they need to effect change in their own communities".

The key purpose of CSR in a community is to "work with communities experiencing disadvantages, to enable them to collectively identify the needs and rights, clarify objectives and take action to meet these within a democratic framework which respect the needs and rights of others" (Ismail, $2009 \mathrm{p}$ 204).

As a result of globalization, investment in developing countries has brought much attention to corporations responsibility to the local communities in which they operate. Mining operations can adversely affect the local communities as a result of degrading environment, diminishing livelihood prospects as well as displacing them from their homes (Kapelus, 2002). Few studies have been 
conducted in relation to mining companies operating in developing countries (Ite, 2007; Kapelus, 2002). These studies show that corporations are recognizing their responsibilities towards local communities in relation to their rights, values and customs and are incorporating them in their decision-making. Introducing community development programs can benefit the local communities and reduce the negative impact of mining operations to some extent. In the case of the Ok Tedi Mine in Papua New Guinea, mining contributed to about $20 \%$ of the export income, provided employment for thousands of people, investment of $\$ 300$ million in infrastructure such as roads, power, water, communications, schools and medical facilities, education and training for over 1500 people, infant mortality rate declined from $33 \%$ to $3 \%$, improved health increased the life span from 30 to 50 years. It also expanded the educational opportunities for children, established school building and provided small business assistance. Therefore, closing the mine for its negative externalities was not a solution as it was important to economic and social welfare resulting in community development for Papua New Guinea (Australian Graduate School of Management, 2014).

In exploring the issue of CSR, the World Business Council for Sustainable Development (WBCSD) discussed the importance of company involvement and investment in the local community(WBCSD, 1998). This was highlighted in the study conducted by Holme and Watts (2000) that in order to protect the community the company provided skills training and proper health and safety systems. In context of Sri Lanka, engagement of corporate sector in community development is an area currently under researched, requiring further attention.

\section{Context of Sri Lanka}

Sri Lanka is a developing country that emerged out of 30 years of civil war in 2009. During this period a large percentage of the budget was allocated to war expenses which deprived the country of resources for economic development. According to the World Bank (2014) around 80\% of the population in Sri Lanka lives in rural areas and 90\% are considered poor (World Bank, 2010). Even though raising the standard of living is the responsibility of the government of Sri Lanka, they do not have the capacity to reach the poor due to the income deficit in their budgets. As a result, the World Bank, NGO's and voluntary organisations are providing support for community development.

In 2013, a revision to the 2008 code of best practice on corporate governance was issued by SECSL and ICASL. (2013). Principle G of the code refers to sustainability reporting. Principle G1.4 states "society governance encompasses support for and building a relationship with the community and striving for sustainable development including responsible public policy participation, fair competition and responsible community involvement"(SECSL \& ICASL., 2013 p 26).

However, in Sri Lanka, basic compliance and enforcement of laws is weak. Therefore, CSR as a corporate strategy that goes beyond legal compliance can have significant positive effects on the poor and minimize negative externalities (Werner, 2009).

\section{CSR and Community Development in the Sri Lanka}

\section{Voluntary and Non-Government Organisation Involvement}

In Sri Lanka, voluntary organisations play an important role in providing the basic human needs such as day care centres, nursery schools, health clinics, homes for destitute children and homes for the elderly; they also provide vocational training, non-formal education and sports and recreation programs. They operate rural development projects and community self-help programs providing social overhead capital such as roads, water tanks, irrigation canals, sanitation facilities and wells (Perera, 2001). 
Many community development projects are also being carried out by Non-Government Organisations (NGO). Sarvodaya Shramadana Movement is the largest people's organization in Sri Lanka. It has reached the poor rural communities through rural community development programs throughout the island. They are currently involved in resettlement, reconstruction and reconciliation activities in the war affected North and East of Sri Lanka. Among the many community development programs they carry out are community capacity building, education, health, empowerment of women, entrepreneur development (Sarvodaya, 2014). Among other projects were Gemi Diriya project which enabled poor to improve their livelihood and quality of life through their various programs for skills development and employment (World Bank, 2010), Sevalanka, provides micro- finance to community organisations and rural entrepreneurs (Sevalanka Foundation, 2014) and Community Development Centre work to improve the livelihood of rural population through conservation of indigenous tuber varieties using seed banks managed by women-led self- help groups (UNDP, 2012).

Government organisations such as Economic Development Ministry has launched a special program and have trained over 1825 people under their Community Development and Livelihood improvement project (Ministry of Economic Development, 2014).

\section{Corporate sector involvement in CSR and Community development}

Sri Lanka has a long history of corporate philanthropy. Charitable activities performed by the business communities to support various needs of the society is not a new concept in Sri Lanka (Ariyabandu \& Hulangamuwa, 2002). The impact CSR has on economic development has resulted in Sri Lanka's corporate sector organisations including CSR in their strategy is evidenced in the annual reports of listed companies in Sri Lanka.

Ariyabandu and Hulangamuwa (2002) categorize the main forms of CSR activities observed in Sri Lanka as philanthropic and charitable activities, environmental conservation, public awareness and corporate sponsorships (Ariyabandu \& Hulangamuwa, 2002). Many companies are engaged in CSR activities related to community development, due to the fact that CSR related activities provide competitive advantage and corporate reputation leading to better performing share prices (Husted \& Allen, 2007). The CSR activities companies are engaged in Sri Lanka are related to education, health, unemployment, entrepreneur development, employee welfare and provision of infrastructure facilities. There are others who concentrate on environmental issues such as reducing the pollution associated with poverty, reduction of greenhouse gas emissions and cleaning beaches. The activities that relate to rebuilding the communities in Sri Lanka includes support educational needs, health and environmental issues, housing, providing entrepreneurship programmed and vocational training to youths to reduce unemployment. Improvement of local living conditions by providing water and sanitation are also included (Heenetigala, 2011).

The report from the survey conducted by International-Alert (2005)also states that the reasons for engaging in CSR activities in Sri Lanka were reported as image building, long-term benefits to current investment and a transparent relationship with society in dealing with controversial products. In 2007, $75 \%$ of the top fifty listed companies in Sri Lanka disclosed their CSR initiatives in their annual reports (Heenetigala, 2011). Fernando (2007) states that according to a survey conducted by International Alert in 2004, $73.2 \%$ companies had a CSR policy, and $17 \%$ of those, had a formal written policy with $84.1 \%$ of the companies engaged in CSR because they genuinely contributed to the betterment of society.

Today, corporate sector in Sri Lanka and around the world is engaged in corporate social responsibility activities as a part of their corporate strategy, because CSR is considered "an important tool to maximize the positive development impact of corporations and community development activity in the developing world" (Werner, 2009). Private sector participation in sustainable community development enhances their social status and competitive edge which is important to their existence (Moon, 2007). 


\section{Theoretical Perspective of CSR and Community Development}

Based on the impact that the community development has on organisations, this study considers the importance of corporate social responsibility activities related to community development. Community is a major stakeholder who can substantially affect or affected by the activities of others (Jensen, 2001). Therefore, the theoretical perspective of this research is based on the stakeholder theory. According to the view of stakeholder theory a corporation is a social entity and effects the welfare of many people who are considered to have a stake in the organisation (Donaldson \& Preston, 1995; Freeman, 1984). They can be instrumental in the success of the corporation and have a moral and a legal right to have their claims recognised (Donaldson \& Preston, 1995). Therefore, the claims of the stakeholders should be considered in their decision-making, because it enhances efficiency (Turnbull, 1994). Accordingly, those companies that are proactive establish necessary governance structures and integrate stakeholders concerns in their decision-making process (De Wit, Wade, \& Schouten, 2006). These firms go beyond their financial responsibility and consider the impact of environmental and social aspects of their operations on society (Spitzeck, 2009).

A stakeholder theory perspective redefines the purpose of business and its method of responding to non-economic factors. From this perspective there are a number of stakeholders among which community is also important. Therefore, proponents of stakeholder theory argue that it is appropriate to sacrifice excess profits in the public interest (Rahim, 2011).

Clarkson (1995) identified two categories of stakeholders, who are considered as the primary and secondary stakeholders. Primary stakeholders are those that are essential to survival of the firm, whereas the secondary stakeholders are those that influence or are being influenced by the firm. Therefore, according to Adewuyi and Olowookere (2010) a community is a stakeholder in both categories.

The stakeholder model introduced by Heenetigala (2011) states that directors' accountability extends to all stakeholders who are directly or indirectly affected by the actions of the firm. Key features of the model in that study was that CSR of the firms that operate in Sri Lanka should focus on developing the communities in which they operate. As stated above, $80 \%$ of the population that lives in rural areas are considered poor. They lack basic infrastructure and facilities to improve their living standards. Therefore, firms and communities can benefit through the development of these communities and gain new markets, increase financial performance and obtain higher market value for the shares, and communities can benefit from economic development.

The stakeholder versus shareholder model (Heenetigala, 2011) suggests that CSR initiatives focused on lower income communities can improve their living standards resulting in increased performance of companies in the long term. As a result, the corporate strategy of boards needs to incorporate CSR strategies directed at the rural disadvantage communities to create jobs and improve income for socioeconomic development.

\section{Methodology}

As discussed in the above, corporate sector involvement in community development practices as a CSR strategy can have a strong impact on improving the living standards and performance in the long term. To investigate the CSR practices related to community development in Sri Lanka, this study explored a sample of 30 companies from the top 50 listed companies in the Sri Lanka's LMD 100 for the year 2013. The companies selected were at the top rank based on their annual turnover. The companies were also ranked among the most respected companies in Sri Lanka. The ranking of the most respected companies was based on the opinions expressed by respondents through a survey conducted by Nielsen to find out why they perceived them as being the 'most respected' by their peers in the commercial capital. 
The data were collated from secondary data disclosed in annual reports published on websites of companies. Websites of the 30 companies were examined for evidence of CSR reporting, whether they had a sustainability report, an integrated report, or if they reported their CSR in their website, as well as their community development practices related to CSR. The top 10 companies were examined indepth to understand the CSR related community development practices. Information related to CD practices was reported under the themes of education, health, employment, community/livelihood development, disaster relief and corporate philanthropy. This is a qualitative study using content analysis to analyse the CSR information reported in websites as well as sustainability reports and integrated reports. Content analysis is a "set of procedures for collecting and organizing information in a standardized format that allows analysts to make inferences about the characteristics and meaning of written and other recorded material" (United States General Accounting Office, $1989 \mathrm{p} \mathrm{6)}$ ). This methodology also helps to summarize the material by listing or counting the issues or statements, which has been addressed in the next section.

\section{Analysis of CSR activities in Sri Lanka}

Investigation of websites of companies in the sample revealed that $87 \%$ of the companies reported CSR activities through their websites, integrated reports and sustainability reports. CSR practices were reported in their websites by $40 \%$ of the companies, $66.67 \%$ had an integrated report, $10 \%$ had a separate sustainability report and 3.3\% reported on the website as well as in the integrated report or sustainability report. This shows that the current trend is moving toward integrated reporting.

Over $73 \%$ of companies reported that they conducted CSR related to community development. CD practices of companies in the sample revealed CSR related community development practices varied from education, health, sanitation, clean water, infrastructure, entrepreneurial development, disaster management and employment..

Education, health and community and livelihood development activities were among the top community development practices conducted by the companies in Sri Lanka. As reported earlier, Sri Lanka is a developing country and $80 \%$ of the people live in rural areas and $90 \%$ of them are considered poor. However, according to UNICEF (2013) Sri Lanka reports a literacy rate of 91\%, which is considered high for a developing country. As reported by Matten and Crane (2005) education is a major activity conducted by Toyota to be considered a good corporate citizen. CSR related to community development in Sri Lanka is also geared towards education which is also the reason for high literacy rate.

Eight out of the ten companies investigated reported on CSR initiatives in education. Education is considered important even among the poor people living in rural areas in Sri Lanka. Analysis shows that English education and IT is considered the top most priority among the companies. IT skills and English literacy is considered important for employability in the private sector as well as the public sector. Among other initiatives to promote education are infrastructure facilities for schools such as building class rooms, IT labs, sporting facilities, toilets, water filteration system and library facilities. A study conducted by Anthonisz (2008) reported companies in Sri Lanka provided scholarships, educational infrastructure and English language training for rural students.

Many companies also provided scholarships for outstanding under-privileged university students and for those studying for Ordinary level and Advanced level exams. The impact of education uplifts the socio-economic prospects in life, with trickle down effects to the entire society (Expolanka Holdings Plc, 2013). This confirms a previous findings in a study conducted by Jamali (2008) that CSR in a developing country context, education and learning programs were reported in their community investment related to CSR.

Nine of the ten companies that were examined in the sample carried out community/livelihood development projects. These CSR projects varied in their context. Different types of livelihood projects were carried out by the companies. They included cashew farming, milk collection, promoting home growing and gardening, use of local supplies and local services, provided support for farmers to 
increase productivity and training farmers on best practices in crop and animal agriculture. Some companies provided empowerment programs for women and employment of women as well as microfinance for villagers and entrepreneurship programs. Among others were, building water tanks, providing electricity, donation of houses and sporting activities.

\section{Table 1: CSR Related Activities Conducted by Companies in Sri Lanka}

\begin{tabular}{|c|c|}
\hline Themes & Type of Activity \\
\hline Education & $\begin{array}{l}\text { - English Language education } \\
\text { - Scholarship programs } \\
\text { - IT training, facilities and infrastructure } \\
\text { - Infrastructure for schools } \\
\text { - Ponation of books to students } \\
\text { - } \text { Providing opportunities for rural children to demonstrate their talents in art, } \\
\text { - Financial assistance for uniforms and books }\end{array}$ \\
\hline Health & 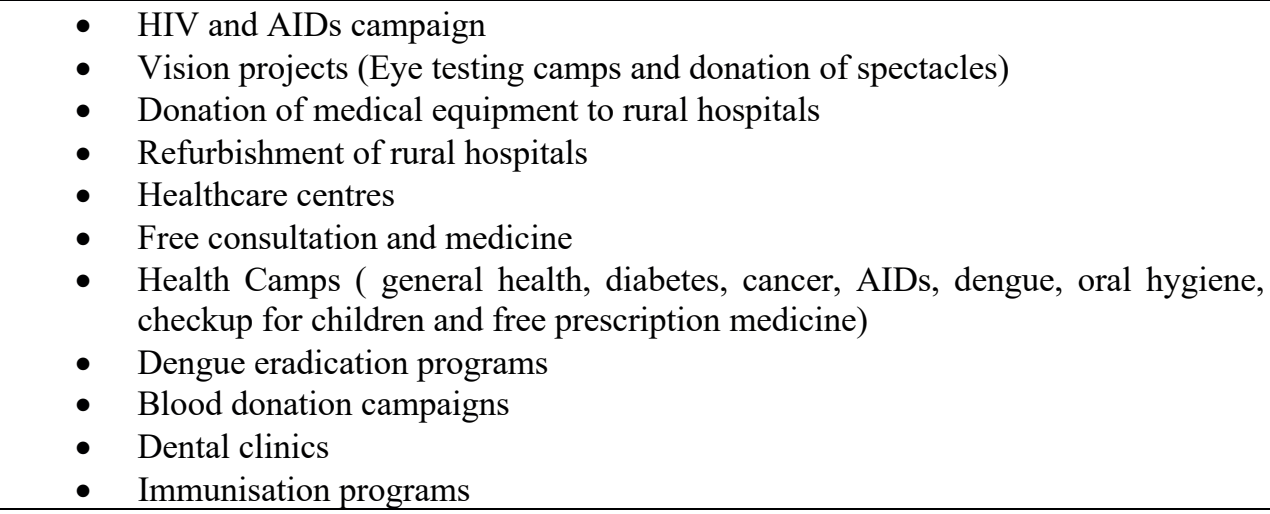 \\
\hline Employment & $\begin{array}{l}\text { - Employing locally, senior management and team members for their operations } \\
\text { in the local areas. }\end{array}$ \\
\hline $\begin{array}{l}\text { Community/ } \\
\text { Livelihood } \\
\text { Development }\end{array}$ & 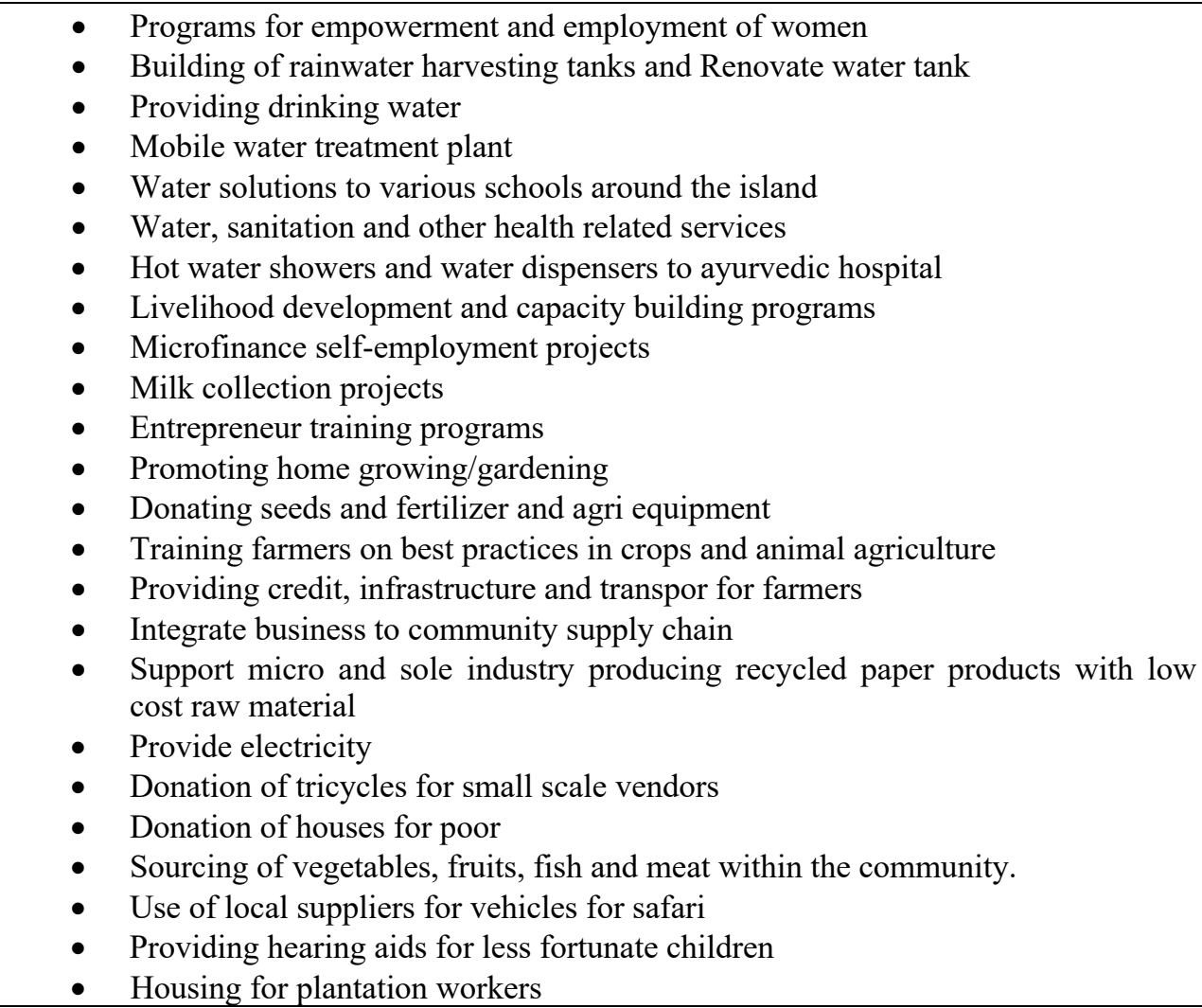 \\
\hline
\end{tabular}




\begin{tabular}{|c|c|}
\hline & $\begin{array}{ll}\text { - } & \text { Commitment to improve sports activities such as volley ball, football and cricket } \\
\text { - } & \text { Providing refreshments for pilgrims } \\
\text { - } & \text { SMS service for blood donor service }\end{array}$ \\
\hline Environment & $\begin{array}{l}\text { - Programs to raise the awareness on the need to protect the environment and } \\
\text { biodiversity, eco-friendly practices and the importance of co-existing in } \\
\text { harmony with the environment for school children and other interested groups } \\
\text { - Paper conservation projects - waste paper collection, shredding and recycling: } \\
\text { Aim is to save trees and reduce waste paper ending in landfills } \\
\text { - Reduce using polythene bags in supermarkets and replace with reusable bags } \\
\text { - Collection of plastic bottles for recycling } \\
\text { - Providing solar power for selected number of villages: sustainable energy } \\
\text { initiatives }\end{array}$ \\
\hline Arts & $\begin{array}{l}\text { - Support the annual fair to display and sale of art by artists around the island } \\
\text { - Launched the first digital art gallery for Sri Lankan artists to show case their } \\
\text { work at Sri Lankan art gallery } \\
\text { - Support Sunera Foundation, a program aimed at fostering aesthetic talents of } \\
\text { school children in national schools and also recognizing and rewarding for their } \\
\text { skills }\end{array}$ \\
\hline Disaster Relief & 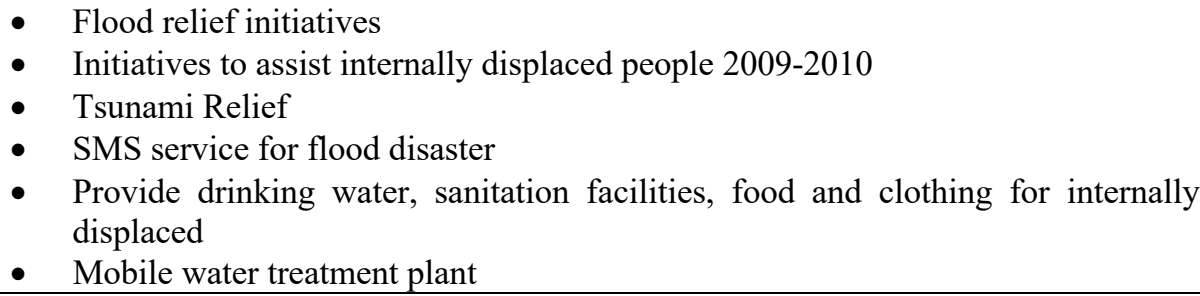 \\
\hline $\begin{array}{l}\text { Corporate } \\
\text { Philanthropy }\end{array}$ & $\begin{array}{l}\text { - } \text { Holding medical camps } \\
\text { - } \quad \text { Blood donations campaigns } \\
\text { - } \quad \text { Donations of medical items and other supplies to Hospitals } \\
\text { - } \\
\text { - } \quad \text { Visit to cancer hospital children's section with gifts, sweets, entertainment and } \\
\text { medication } \\
\text { - Lending a hand to elders, time with children in orphanges, donation to Kidney } \\
\text { protection society, help differently able persons, donation of bicycles to school } \\
\text { children, support education of rural schools through contribution of stationery } \\
\text { Identify young sports talent and support them }\end{array}$ \\
\hline
\end{tabular}

Five out of ten companies reported on the health initiatives by companies. Among the health programs, they conducted were, HIV and AIDs awareness, eye testing, dental clinics, immunization for children campaigns, hospital refurbishment and free health clinics for people in rural areas.

Community development efforts by the companies are geared towards supporting the rural communities to improve and maintain their capabilities and to sustain their socio-economic progress and quality of life of the people living in the poor rural communities.

To a lesser degree companies were carrying out programs supporting art and fostering aesthetic talent among children in village schools. They were also providing relief for internally displaced people from North and East. These include food, clothing, water and sanitation. They also provided flood relief programs for effected flood victims and also created blood donor SMS and flood disaster SMS service.

It can be seen from this research that the key areas of CSR related community development are economic empowerment, human capital development, healthy living and provision of basic services by the companies in Sri Lanka. The following table shows the CD activities related to CSR that has been carried out by the private sector in Sri Lanka.

Community is a major stakeholder especially in developing countries such as Sri Lanka. The rural community is a major part of the population in Sri Lanka which lacks of facilities such as 
infrastructure, education, healthcare and training to improve their level of income. Therefore, corporations' responsibilities to consider these stakeholders in their business strategies is important, as it can have a significant impact on the rural communities, increase in the demand for their products and services and on the corporate performance.

Therefore the companies that operate in Sri Lanka must listen to the needs of the rural communities in which they operate, because they make a large part of Sri Lanka's population and their ability to participate in the democratic political process is also influenced by not only their level of literacy but also their level of general education and their economic empowerment.

\section{Conclusion}

The findings of this study showed that the companies in Sri Lanka are moving towards integrated reporting and that the majority of the companies conducted CSR related to community development. Community development practices related to education, health and livelihood development activities were among the most important CSR practices that were conducted by the corporate sector. Companies that provide community related CSR in developing countries are considered good corporate citizens. In this context good corporate citizen not only must meet the legal, ethical and economic responsibilities placed on them, they must aim to create a high standard of living and quality of life in the communities in which they operate. It is only through this, that companies can create value for shareholders. Inclusion of $\mathrm{CD}$ in the business strategies can have a strong impact on the performance of private sector companies.

This study also shows that education is a high priority in Sri Lanka. As a result CSR strategies of the corporate sector concentrate on education as well as providing infrastructure for educational institutes in rural areas.

Companies that provide education, health facilities, employment and training and support community/livelihood development projects will be able to increase the share of the market for their products from the communities they develop as well have a positive impact on economic development of the country. In Sri Lanka, rural communities face many challenges due to lack of well-developed infrastructure that negatively affect the quality of lives of people which needs to be addressed by the governments. However, this study shows that the corporate sector is impacting the economic development to some extent through their CSR programs especially the community development component.

It can be concluded that corporate social responsibility policies such as education, health and community livelihood activities are adopted by companies not only because they are socially desirable, they also have a strong impact on the business. Therefore, in the context of Sri Lanka, companies need to identify the social demands of the communities and address those in their CSR strategies for development of the rural communities.

\section{Reference}

Adewuyi, A., O,, \& Olowookere, A., E,. (2010). CSR and sustainable community development in Nigeria: WAPCO, a case from cement industry. Social Responsibility Journal, 6(4), 522-535.

Ajayi, A. R. (1995). Community self-help projects implementation procedures: a case study of Ekti South-West Local Government Area of Ondo State. Agrosearch, 1(1), 47-55.

Akresh, R., Lucchetti, L., \& Thirumurthy, H. (2012). Wars and child health: evidence from the Eritrean-Ethiopian conflict. Journal of Development Economics, 99, 330-340.

Anthonisz, T. (2008). Corporate Social Responsibility of Sri Lanka: A National Business Systems Perspective. (Master of Arts), UNiversity of Nottingham UK, UK.

Ariyabandu, M. M., \& Hulangamuwa, P. (2002). Corporate Social Responsibility and Natural Disaster Reduction in Sri Lanka. Colombo: ITDG - South Asia. 
Australian Graduate School of Management. (23 November 2015). The Environment: BHP and OkTedi,. from http://www.agsm.edu.au/bobm/teaching/BE/Cases_pdf/Ok_Tedi.pdf

Australian Graduate School of Management (Producer). (2014, 04 July 2014). The Environment: BHP and OkTedi. Retrieved from http://www.agsm.edu.au/bobm/teaching/BE/Cases_pdf/Ok_Tedi.pdf

Clarkson, M. B. E. (1995). A Stakeholder Framework for Analysing and Evaluating Corporate Social Performance. Academy of management Review, 20(1), 92-117.

De Wit, M., Wade, M., \& Schouten, E. (2006). Hardwiring and Softwiring Corporate Responsibility: a Vital Combination. Corporate Governance, 6(4), 491-505.

Donaldson, T., \& Preston, L. E. (1995). The Stakeholder Theory of the Corporation:Concepts, Evidence and Implications. Academy of Management Review, 20(1), 65-91.

Dupas, P., \& Robinson, J. (2012). The (hidden) costs of political instability: evidence from Kenya's 2007 election crisis. Journal of Development Economics, 99(314-329).

Elborgh-Woytek, K., Newiak, M., Kochhar, K., Fabrizio, S., Kpodar, K., Wingender, P., . . Schwartz, G. (2013). Women, Work, and the Economy: Macroeconomic Gains From Gender Equity: International Monetary Fund: Strategy, Policy, and Review Department and Fiscal Affairs Department.

Eweje, G. (2006). The Role of MNEs in Community Development Initiatives in Developing Countries: Corporate Social Responsibility at Work in Nigeria and South Africa. Business \& Society, 45(2), 93-129.

Expolanka Holdings Plc. (2013). Annual Report (pp. 155). Sri Lanka.

Fernando, M. (2007). Corporate Social Responsibility in the Awake of the Asian Tsunami: A Comparative Case Study of Two Sri Lankan Companies. European Management Journal, 25(1), 1-10.

Fisher, K., Greenen, J., Jurcevic, M., McClintock, K., \& Davis, G. (2009). Applying asset-based community development as a strategy for CSR: a Canadian perspective on a win-win for stakeholders and SMEs. Business Ethics: A European Review, 18(1), 66-82.

Freeman, R. E. (1984). Strategic Management: A Stakeholder Approach. Boston, MA: Pitman Publishing.

Hamann, R., Woolman., S., \& Sprague, C. (2008). The business of sustainable The business of sustainable development in Africa: Human rights, partnerships, alternative business models development in Africa: Human rights, partnerships, alternative business models. Pretoria, South Africa: UNISA Press.

Heenetigala, K. (2011). Corporate Governance Practices and Firm Performance of Listed Companies in Sri Lanka,. (DBA), Victoria University, Melbourne, Australia.

Holme, R., \& Watts, P. (2000). Corporate Social Responsibility: Making Good Business Sense: World Business Council for Sustainable Development.

Husted, B. W., \& Allen, D. B. (2007). Strategic Corporate Social Responsibility and Value Creation among Large Firms Lessons from the Spanish Experience. Long Range Planning, 40, 594610.

Idemudia, U. (2007). Corporate partnerships and community development in the Nigerian oil industry: Strengths and limitations Program Paper, Markets, Business and Regulation, Paper No. 2. Geneva, Switzerland: United Nations Research Institute for Social Development (UNRISD).

International-Alert. (2005). Peace Through Profit: Sri Lankan Perspectives on Corporate Social Responsibility (pp. 148). London: International-Alert.

Ismail, M. (2009). Corporate Social Responsibility and its Role in Community Development: An International Perspective. The Journal of International Social Research, 2(9), 199-209.

Ismail, M., Alias, S. N., \& Rasdi, R. M. (2015). Community as a stakeholder of the corporate social responsibility programme in Malaysia: out comes in community development. Social Responsibility Journal, 11(1), 109-130.

Ite, U., E.,. (2007). Changing Times and Strategies: Shell's Contribution to Sustainable Community Development in the Niger Delta, Nigeria. Sustainable Development, 15, 1-14.

Jamali, D. (2008). A Stakeholder Approach to Corporate Social Resposibility: A Fresh Perspective into Theory and Practice. Journal of Business Ethics, 82, 213-231. 
Jensen, M., C. (2001). Value Maximization, Stakeholder Theory and the Corporate Objective Function. Journal of Applied Corporate Finance, 14(3), 8-21.

Kapelus, P. (2002). Mining, Corporate Social Responsibility and the Community: The Case of Rio Tinto, Richards Bay Minerals and the Mbonambi. Journal of Business Ethics, 39, 275-296.

Kemp, D. (2010). Mining and community development: problems and possibilities of local-level practice. Community Development Journal, 45(2), 198-218.

Kolk, A., \& Lenfant, F. (2010). MNC reporting on CSR and conflict in central Africa. Journal of Business Ethics: A European Review, 93, 241-255.

Matten, D., \& Crane, A. (2005). Corporate Citizenship: Towards an Extended Theoretical Conceptualization. Academy of Managment Review, 30(1), 166-179.

Ministry of Economic Development. (2014). Second Community Development and Livelihood Improvement Project. Retrieved 8th July, 2014, from http://www.gemidiriya.org/

Moon, J. (2007). The Contribution of CSR to Sustainable Development. The Journal of Sustainable Development, 15, 296-306.

Muthuri, J. N., Moon, J., \& Idemudia, U. (2012). Corporate Innovation and Sustainable Community Development in Developing Countries. Business \& Society, 5(3), 355-381.

Nasi, J., Nasi, S., Phillips, N., \& Zyglidopoulos, s. (1997). The Evolution of Corporate Social Responsiveness. Business \& Society, 36, 296-321.

Obibuaku, L. O. (1983). Agricultural Extension as a Strategy for Agricultural Transformation. Nsukka, Engu State Nigerai: University of Nigeria Press,.

Perera, B. (2001). Impact of Decentralisation on Rural Development at Local Level: Country Case Study Sri Lanka. In F. a. A. Organisation (Ed.), Decentralized Rural Development and the Role of Self Help Organizations. Bangkok: RAP Publication.

Rahim, M. M. (2011). The 'Stakeholder approach' to Corporate Governance and Regulation : An assessment. Macquarie Journal of Business Law, 8, 304-325.

Sarvodaya. (2014). Empowerment programmes. Retrieved 07th July 2014, from http://www.sarvodaya.org/about/empowerment-programmes

SECSL, \& ICASL. (2013). Code of Best Practice of Corporate Governance 2013: The Securities Exchange Commission of Sri Lanka, The Institute of Chartered Accountants of Sri Lanka.

Sevalanka Foundation. (2014). Sevalanka Foundation. Retrieved 08 July, 2014, from http://www.sevalanka.org/

Spitzeck, H. (2009). The Organizational Structures and Processes: The Development of Governance Structures for Corporate Responsibilty. Corporate Governance, 9(4), 495-505.

Turnbull, S. (1994). Stakeholder Democracy: Redesigning the Governance of Firms and Bureacracies. Journal of Socio-Economics, 23(3), 321-361.

UNDP. (2012). Community Development Centre Sri Lanka Equator Initiative Case Study Series. New York.

UNICEF. (2013). Sri Lanka: Statistics. Retrieved 9 July, 2015, from http://www.unicef.org/infobycountry/sri lanka statistics.html

United States General Accounting Office. (1989). Content Analysis: A Methodology for Structuring and Analyzing Written Material Transfer Paper 10.1.3. United States: General Accounting Office.

Valente, M., \& Crane, A. (2010). Public responsibility and private enterprise in developing countries. California Management Review, 52, 52-78.

Van Niekerk, R. (2012). Revisiting history: the creation of provinces and the politics of social policy in a democratic South Africa. Social Policy \& Administration, 46, 619-635.

WBCSD. (1998). Stakeholder Dialogue on CSR. Paper presented at the The Netherlands September 6$8,1998$.

Werner, W. J. (2009). Corporate Social Responsibility Initiatives Addressing Social Exclusion in Bangladesh. Journal of Health Population and Nutrition, 27(4), 545-562.

Whellams, M. (2007). The Role of CSR in Development: A Case Study Involving the Mining Industry in South America. ( Masters of International Development Studies), Saint Mary's University, , Halifax, Nova Scotia. 
Wicks, A., \& Berman, S. (2004). The Effwcts of Context of context in Trust in firm-stakeholder relationships: The institutional environment, trust creation and firm performance. Business Ethics Quarterly, 14(1), 141-160.

World Bank. (2010). Community Development and Livelihood Improvement "GEMI DIRIYA"

Project: Sustainable Development Department Agriculture and Rural Development Unit South Asia Region, World bank.

World Bank. (2014). Sri Lanka: Priorities for Agriculture and Rural Development. from http://web.worldbank.org/WBSITE/EXTERNAL/COUNTRIES/SOUTHASIAEXT/EXTSAR EGTOPAGRI/0,,print:Y isCURL:Y contentMDK:20273817 menuPK:548217 pagePK:340 04173 piPK:34003707 theSitePK:452766,00.html 